Haya: The Saudi Journal of Life Sciences

Abbreviated Key Title: Haya Saudi J Life Sci ISSN 2415-623X (Print) |ISSN 2415-6221 (Online) Scholars Middle East Publishers, Dubai, United Arab Emirates Journal homepage: https://saudijournals.com/sjls

Original Research Article

\title{
Evaluation of Pharmacological Features and Nanoparticle Formation by Urena lobata
}

Dinesh Kumar, Somendra Kumar, Motiram Sahu, Anil Kumar*

Department of Biotechnology, Government V.Y.T. PG. Autonomous College, Durg, Chhattisgarh, India

DOI: $10.36348 /$ sjls.2020.v05i10.006

| Received: 28.09.2020 | Accepted: 22.10.2020 | Published: 30.10.2020

*Corresponding author: Anil Kumar

\section{Abstract}

Urena lobata commonly known as Congo jute or hibiscus burr is a shrub belonging to the family Malvaceae widely distributed throughout India. The plant is utilized by the traditional healers for various ailments such as arthritis, diabetes, cough and malaria. In the present study, phytochemical constituents and antioxidant property of Urena lobata was studies in both normal extract and silver nanoparticle form. The antioxidant property of leaf of the plant was also evaluated. We have reported alkaloid, saponin, steroid, terpenoid, tannin, flavonoid and carbohydrate and significant antioxidant activity by DPPH method from this plant. For the first time, silver nanoparticle was successfully synthesized using Urena lobata leaf extract in the current investigation and characterized by UV-VIS spectrophotometer and the characteristic surface plasmon resonance peak was identified to be $\square 424 \mathrm{~nm}$. X-ray diffraction (XRD) was employed to ascertain the crystalline nature and purity of the silver nanoparticles which implied the presence of 111, 002, 022, 113, and 222 lattice planes of the cubic structure of metallic silver and Fourier transform infrared spectroscopy (FTIR) was used to determine specific functional groups in silver nanoparticles and the capping agents present in the leaf extract.

Keywords: Urena lobata, diabetes, saponin, Fourier transform infrared spectroscopy (FTIR).

Copyright @ 2020: This is an open-access article distributed under the terms of the Creative Commons Attribution license which permits unrestricted use, distribution, and reproduction in any medium for non-commercial use (NonCommercial, or CC-BY-NC) provided the original author and source are credited.

\section{INTRODUCTION}

The plant with precious medicinal properties continues to obtain a keen awareness by several scientists for the complete range of biological activities, which range from antibiotics to antitumor. Plants and natural products have long played a crucial role in the treatment of various illnesses either as pure compounds or as extracts. They offer an invaluable source of compounds with a wide variety of chemical structures, biological activities and provide important prototypes of the development of novel drugs. There is a huge range of compounds that can be extracted and characterized by plants. Extraction of bioactive compounds from medicinal plants permits the exhibition of their physiological activity. Malaria is among the most dreaded diseases of the twentieth century and spreading further with the continuance and increasing frequency in the century. Urena lobata Linn. (Commonly known as Caesar weed, Congo jute) is a shrub (60-100 $\mathrm{cm}$ in length) belonging to the Malvaceae family, widely distributed throughout India. The active constituents of the plant are flavonoids glycoside, alkanes, $\beta$-sitosterol stigma-sterol, furocoumarin, imperatorin, mangiferin and quercetin
[1]. Various extracts of the leaves and roots of the plant are used in herbal medicine to treat varied ailments such as cough, malaria, venereal diseases, wounds, toothache, and rheumatism. It also serves as food material for humans as well as animals [2]. It is reported that urenalobasides, a megastigmane glycosides of $U$. lobata inhibits in vitro production of nitric oxide in lipopolysaccharide-stimulated RAW 264.7 macrophage cells [3]. Oral administration of aqueous extract $U$. lobata leaves at different doses was found effective to altered the blood glucose and insulin levels and increases the glucagon-like peptide (GLP)-1 levels in diabetic rats [4]. Alcohol root extracts from $U$. lobata possess significant protective effect against $S$. aureus pneumonia and combined therapy of these extracts with Cefazolin sodium have shown additive effects [5]. Clematoside- $\mathrm{S}$ a triterpenoid saponin isolated from the leaves of $U$. lobata showed to possess anti-yeast activity. There is an increasing demand for clean, biocompatible, and eco-friendly techniques so many biological approaches for both extracellular and intracellular nanoparticles synthesis have been reported using microorganisms including bacteria, fungi and plants [6, 8]. Plants provide a better platform for nanoparticles synthesis, provide natural capping agents 
and also reduces the cost of microorganisms isolation and culture media [7]. Silver nanoparticles have been found to possess both anti-bacterial and antiinflammatory properties and that is why it has been integrated into many commercially available wound dressings, pharmaceutical preparations, and medical implant coatings, but, there is still need for economic commercially viable as well as environmentally clean synthesis route to synthesize the silver nanoparticles. In the textile industry, silver-embedded fabrics are now used in sporting equipment [9-12]. Various metal nanoparticles synthesis have been reported using fungi like Fusarium oxysporum, Penicillium sp. and using some bacteria such as Bacillus subtilis etc [13-15] but, synthesis of nanoparticles using plant extracts is the most advantageous for green, eco-friendly production of nanoparticles because plants are widely distributed, easily available, much safer to handle and act as a source of several metabolites [16]. Several medicinally important plants viz. Oryza sativa, Helianthus annus, Saccharum officinarum, Sorghum bicolour, Zea mays, Basella alba, Aloe vera Capsicum annuum, Magnolia kobus, Medicago sativa (Alfalfa), Camellia sinensis, Azadirachta indica), Cinamomum camphora, and Geranium sp., marigold flower, Ziziphora tenuior, Abutilon indicum, Solanum tricobatum, Erythrina indica, beetroot, Ocimum tenuiflorum, Spirogyra varians, Melia dubia, olive, have been used for synthesis of silver nanoparticles, in the field of pharmaceutical applications and biological industries [17].

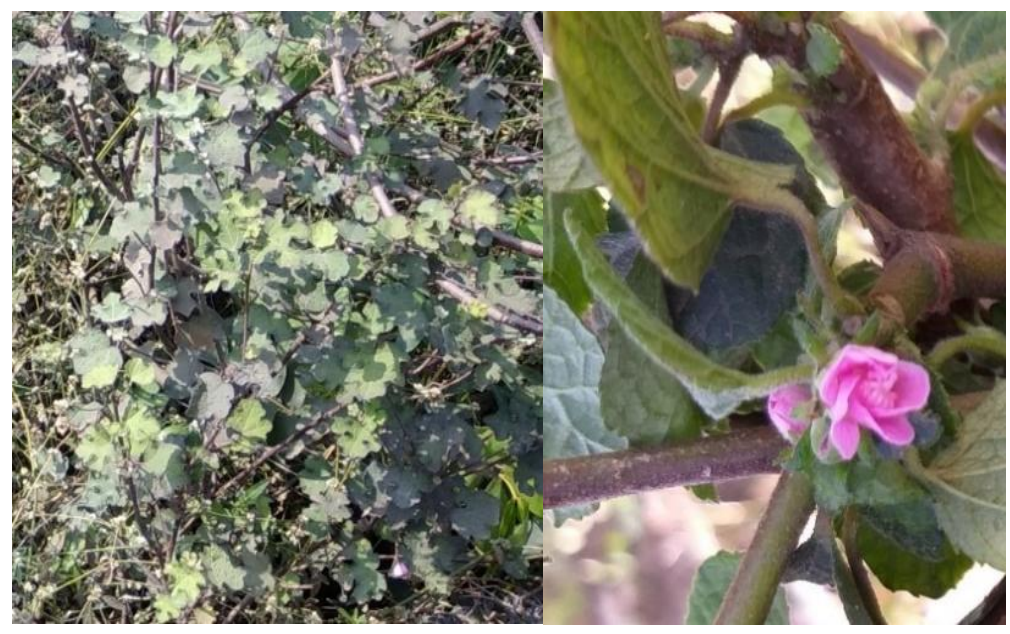

Fig-1: Urena lobata plant in the wild and its flower

\section{MATERIALS AND METHOD \\ Collection of Plant Material}

Healthy plant leaves, stem and roots were collected carefully from Malviya Nagar Square, Durg, Chhattisgarh, India. Plant materials were first washed with running tap water and then three-time with distilled water and dried in shade. After drying plant materials were placed in sterile plastic bags in a dark and cool place until use.

\section{Phytochemical Screening \\ Extraction of Metabolite}

Dried leaf, stem, and root of the plant Urena lobata was submerged into three different solvents distilled water, methanol, and chloroform and was extracted with the help of soxhlet extraction unit (MSW India) sequentially. Extract of these plant material was then tested for major phytochemical groups like alkaloids, cardiac glycoside, flavonoids, saponin, steroids, tannin, terpenoids [18-20]

\section{Test for steroids}

$0.5 \mathrm{ml}$ of the extract was dissolved in $3 \mathrm{ml}$ of chloroform. The solution was filtered, $2 \mathrm{ml}$ of concentrated sulfuric acid was added and a reddish- brown colour ring at the interface was obtained as a steroid.

\section{Test for saponin}

$0.5 \mathrm{ml}$ of the extract was taken in a test tube then $5 \mathrm{ml}$ of distilled water was added to it. The solution was vigorously shaken and stable persistent was observed for the presence of saponin.

\section{Test for tannins}

$0.5 \mathrm{ml}$ of extract and $5 \mathrm{ml}$ of ed water was taken in a test tube, $1 \%$ ferric chloride was added. A deep green, colour appeared which indicated the presence of tannin.

\section{Test for flavonoid}

$0.5 \mathrm{ml}$ plant extract and $5 \mathrm{ml}$ of distilled water were added to the test tube then it was filtered. $5 \mathrm{ml}$ of dilute ammonium solution was added to the filtrate and then concentrated with $0.5 \mathrm{ml}$ sulfuric acid. A yellow colour appeared which indicated the presence of flavonoid.

\section{Test for alkaloid}

$0.5 \mathrm{ml}$ of the extract was taken and $3 \mathrm{ml}$ of methanol was added to it. Then 300 microlitre of acetic 
acid ammonium hydroxide was added dropwise. A precipitate appeared which indicated the presence of alkaloid.

\section{Test for cardiac glycoside}

$0.5 \mathrm{ml}$ of the extract was treated with $0.2 \mathrm{ml}$ glacial acetic acid then dropwise $3.5 \%$ ferric chloride was added to the solution. This was layered with $1 \mathrm{ml}$ of concentrated sulfuric acid. A reddish-brown ring appeared at the interface which indicated the presence of cardiac glycoside.

\section{Test for terpenoids}

$0.5 \mathrm{ml}$ extract was added to the test tube then $2 \mathrm{ml}$ of chloroform was mixed to the solution. $3 \mathrm{ml}$ of concentrated sulfuric acid was added to form a lower layer. A reddish-brown colour at the interface appeared which indicated the presence of terpenoids.

\section{Test for phenol}

$1 \mathrm{ml}$ extract was mixed with $1 \mathrm{ml}$ of distilled water and 2 drop $10 \% \mathrm{Fecl} 3$. A blue colour appeared for the phenol group.

\section{Test for sugar test (molish test)}

$2 \mathrm{ml}$ of extract, 2drop of Alfa- napthanol and $2 \mathrm{ml}$ of concentrated sulfuric acid was added to test the presence of sugar. The appearance of violet ring confirmed the presence of sugar.

\section{Test for protein}

$1 \mathrm{ml}$ extract, $4 \% \mathrm{NaOH}$ were mixed and then 2 drops of $1 \% \mathrm{CuSO} 4$ was added. The appearance of violet colour confirmed the presence of protein.

\section{Test for coumarin}

$1 \mathrm{ml}$ of a plant extract with $1 \mathrm{ml}$ of dilute sodium hydroxide was exposed with UV light and blue fluoresce was reported as confirmation of coumarin.

\section{Evaluation of antioxidant property}

The antioxidant activity of Urena lobata was examined by DPPH (1, 1-diphenyl -2-picrylhydrazyl) method. For this $0.6 \mathrm{mM}$ solution of DPPH was prepared in $100 \mathrm{ml}$ of methanol. For test sample, the plant extract $(1 \mathrm{ml})$ with different concentration $(0.6$, $1.2,2.5,5,10 \mathrm{mg} / \mathrm{ml}$ ) was taken and $1 \mathrm{ml}$ of DPPH was added and final volume of $3 \mathrm{ml}$ was makeup with methanol. The tubes were incubated in dark for 30 minutes then absorbance was taken at $570 \mathrm{~nm}$ and $1 \mathrm{ml}$ $(10 \mathrm{mg} / \mathrm{ml})$ ascorbic acid and methanol was taken as standard and control respectively.

\section{$\%$ of inhibition of DPPH activity $=\frac{\text { Absorbance of control -Absorbance of test }}{\text { Absorbance of control }} \times 100$}

\begin{abstract}
Synthesise of Silver Nanoparticles from Leaf Extract Fresh leaves of Urena lobata washed with distilled water twice followed by Millipore water and left for air-dry overnight. Then 10 gram of plant material was taken with $100 \mathrm{ml}$ of double distilled water in $250 \mathrm{ml}$ of Erlenmeyer flask and kept on a water bath for at $80^{\circ} \mathrm{C}$ for 15 minutes after that plant material was filtered by Whatman filter paper No 1, and then it was reached up to $100 \mathrm{ml}$ with double distilled water. For the synthesis of nanoparticles $10 \mathrm{ml}$ of aqueous leaf extract and $90 \mathrm{ml}$ of $1 \mathrm{mM} \mathrm{AgNO}_{3}$ were mixed and kept on a water bath and incubated for 15 minutes at $80^{\circ} \mathrm{C}$, solution turned into yellowish red-brown indicated the nanoparticle formation [17, 21].
\end{abstract}

\section{Characterization of NanoParticle \\ By Photometric methods and XRD}

Preliminary color transformation into reddishbrown color was observed, spectrophotometric analysis in UV-VIS at range 200 to $600 \mathrm{~nm}$ wavelength was used to monitor the synthesis of silver nanoparticles. Millipore water was used as a standard for baseline correction. X-Ray Diffraction Analysis was used to determine the nature of silver nanoparticles. The fine ground powdered sample was used for analytical material. The analysis was carried out using Bruker- D4 ENDEAVOR XRD-6000/6100 model with 30kv, 30mA with $\mathrm{Cu}$ ka radians at $2 \theta$ angle $10^{\circ}-90^{\circ}$. Debye Sherrer's equation was used for the determination of the particle size of the silver nanoparticles. For the functional group characterization, the particle was dried for 24 hours and the dried silver nanoparticle was scrapped out for characterization using FTIR spectroscopy. The FTIR spectrum was obtained with BRUKER, ALPHA II, ECO ATR, spectrophotometer.

\section{RESULT AND DISCUSSION Phytoconstituents}

Table-1 showed that Tenine, flavonoid, Steroid, Alkaloid, Saponin, Cardiac glycoside, Terpenoid, Sugar and phenols were found from aqueous leaf extract and only Flavonoid, Steroid, Cardiac glycosides, and Terpenoids were found form methanol leaf extract and only Flavonoid was found from chloroform based leaf extract. From stem Tenine, Steroid, Cardiac glycosides, Terpenoid, Sugar, and phenol were found in aqueous-based extracts, Flavonoid, Steroid, Cardiac Glycosides, Terpenoid, and Sugar were found from the methanol-based extract and only Steroid and Terpenoid were found from chloroform based extract. Similarly, phytochemical analysis of root was performed and Flavonoid, Steroid, Alkaloid, Saponin, Cardiac glycoside, Terpenoid, and sugar were found from the aqueous extract. Steroid, Saponin, Cardiac glycoside, Terpenoid, and sugar from methanol extract, and nothing were found from a 
chloroform-based extract of the root of the plant. Conclusively we can state that the leaf part of the plant having maximum secondary metabolite followed by stem and root and the aqueous extract is a more suitable solvent followed by methanol and chloroform for Urena lobata. A similar study by Islam et al, [22], reported alkaloid, glycoside, tannins, steroids, saponins, and reducing sugar however they have not detected terpenoids and flavonoids, while Fagbohun et al., [23] detected only terpenoid and saponin from Urena lobata.

The various phytochemical compounds detected in many plants are known to have beneficial importance in medicinal sciences. For example, flavonoids which showed their anti-allergic, antiinflammatory, anti-microbial and anti-cancer activities. Plant steroids are identified for its cardiotonic activities and also holds insecticidal and antimicrobial abilities and are used in nutrition, herbal medicine and cosmetics (24-25). Tannins were reported to exhibit antiviral, antibacterial and anti-tumour activities. In another study Gao et al., [26] reported anti-yeast activity in terpenoid of Urena lobata. Saponin is a mild cleansing agent, in intracellular histochemical staining and allow access antibody into intracellular proteins. Active substances Stigmasterol, $\beta$-Sitosterol, Mangiferin, Gossypetin, Chrysoeriol in leaf extract of Urena lobata was also reported by liquid chromatography-mass spectrometry among them mangiferin, stigmasterol and $\beta$-sitosterol in was reported strong with inhibitory activity on DPP-IV in-silico [4]. It is also used in various problems like hypercholesterolaemia, hyperglycaemia, antioxidant, anticancer, anti-inflammatory, weight loss, etc. and have antifungal properties as well $[2,27]$. Glycoside an important phytochemical group was found to have an anti-inflammatory effect [3].

\section{Antioxidant Property}

Various medicinal plants have been reported to have a high antioxidant activity where Phenolics and flavonoids are known as the common antioxidants in plants. As we know that phytochemical metabolite also works as defense material against various stress like water stress, temperature, and infection, etc. It was observed that the factor like geographic location of the plant, types of stress and the solvent system used in the extraction process may act as determining a factor for the distribution of these phytochemicals [24, 25]. Several reports are available that shows the presence of phytochemicals such as quercetin, glycosides, rutin, Kaempferol 3-0- $\beta$ glucopyranoside, Quercetin 3-0rutinoside, L-tryptophan, and monordicophenoide A, were reported in Urena lobata [23, 28-29]. In the present study we have observed dose-dependent 1,1 diphenyl-2-picryl-hydrazyl (DPPH) induced free redicle neutralization ability, and the highest $79.62 \%$ DPPH scavenging activity was reported at $10 \mathrm{mg} / \mathrm{ml}$ concentration of Urena lobata plant extract compared to standard ascorbic acid $(10 \mathrm{mg} / \mathrm{ml})$. Similarly Lissy et al., [30] reported significant superoxide radical scavenging, hydroxyl radical scavenging, and lipid peroxidation inhibition activity in Sida retusa, Urena lobata \& Triumfetta rhomboidea in another study Ali et al., [30] reported significant antioxidant activity in Urena lobata fresh leaves. The result of DPPH scavenging activity assay in this study indicates that the plant is potently active. This indicates that the plant extract has certain compounds that are capable of donating hydrogen to a free radical and which is responsible for the free radical's activity. The ability of this plant extract to scavenge DPPH could also reflect its ability to inhibit the formation of Free radicals are known as major contributors to several clinical disorders such as diabetes mellitus, cancer, liver diseases, renal failure and degenerative diseases as a result of deficient natural antioxidant defence mechanism $[24,25,31]$.

\section{Nanoparticle Synthesis and Characterization}

Silver nanoparticles with their distinctive properties are showing to be a substitute for the improvement of new antibacterial agents. It has got a diversity of uses in the form of wound dressings, coatings for medical devices and impregnated textile fabrics, etc. A detailed study on the biosynthesis of silver nanoparticles by Urena lobata was carried out in the present study. Silver ions were found reduced to silver nanoparticles when added to Urena lobata plant aqueous extract. It was observed that the color of the solution turned from yellowish to bright yellow and too dark brown after 15 minutes of the reaction, which indicated the formation of silver nanoparticles confirmed by UV-VIS spectrophotometer analysis. The colloidal solution color change from yellowish to bright yellow and, finally, to dark brown, after 1, 24, and $48 \mathrm{~h}$ of the reaction was reported, indicating the formation of silver nanoparticles because of excitation of surface plasmon vibrations in synthesized silver nanoparticles $[32,33]$.

The synthesized silver nanoparticles in the colloidal solution were monitored by UV-VIS spectrophotometer analysis. Figure 9 shows that the absorption spectra of silver nanoparticles formed in the reaction media have an absorbance peak at approx. 424 $\mathrm{nm}$. correspond to a characteristic of these noble metal particles.

Further, the XRD analysis was carried out to confirm the crystalline nature of the particles, and the XRD pattern showed the number of Bragg's reflections that may be indexed based on the structure of silver. To verify the results of UV-vis spectral analysis, the sample of silver ions exposed to Urena lobata was examined by XRD. The XRD pattern for silver nanoparticles synthesized using Urena lobata and mean particle diameter (d) of silver nanoparticles was calculated from the XRD pattern, according to the line width of the plane, refraction peak, using the following 


$$
\text { Scherrer equation: } D=\frac{K \lambda}{B 1 / 2 \cos \theta}
$$

The equation used the reference peak width at angle $\theta$, where $\lambda$ is the X-ray wavelength (1.5418 $\AA$ ), $\beta 1 / 2$ is the width of the XRD peak at half height and $\mathrm{K}$ is a shape factor. The silver nanoparticles synthesized were calculated by the particle size ranges of the silver 28.17. An XRD spectrum of AgNPs formed in our experiments as demonstrated by the peaks $2 \theta$ values of $38.16,44.28,64.51,77.45$ and 82.18 , corresponding to 111, 002, 022, 113 and 222 respectively, clearly indicated that the AgNPs organized by the reduction of $\mathrm{Ag}+$ ions by the aqueous extract of Urena lobata were crystalline in nature. Various authors have also reported different size of silver nanoparticle viz. 53, 41, 52 and $42 \mathrm{~nm}$, size for Syzygium cumini, Citrus sinensis, Solanum tricobatum, and Centella asiatica, respectively [34], $51 \mathrm{~nm}$ by olive leaf extract [21], $13.07 \mathrm{~nm}$ from Calliandra haematocephala leaf extract [33], 12-20 $\mathrm{nm}$. from saffron (Crocus sativus L.) wastages [36], 66 - $117 \mathrm{~nm}$ using spent tea leaves extract [35]. The FTIR spectrum of Ag NPs synthesized from Urena lobata aqueous extract showed the presence of bands at $1635.93 \mathrm{~cm}-1$, and $3319.67 \mathrm{~cm}-1$ for silver nanoparticle and 1636.40 and 3300.67 for aqueous extract. The existence of peaks at 3319.67 and 3300.67 might be due to the $\mathrm{AOH}$ stretching of alcohols and phenols or bending stretching of hydrogen-bonded alcohols and phenols in the leaf extract and was suggested to be due to the stretching of - $\mathrm{OH}$ in proteins, enzymes or polysaccharides present in the extract. A strong peak at 1620.09 denoted the bending vibrations of the amide I group and arisen due to a carbonyl stretch in the amide linkages of the proteins and suggested the possible binding of silver nanoparticles with the proteins present in the extract [21, 34]. Synthesized Ag NPs were identified as amide I and arose due to a carbonyl stretch in the amide linkages of the proteins. The results of FTIR showed that the secondary structure of the proteins was unaffected as a result of reaction with the $\mathrm{Ag}+$ ions or binding with the silver nanoparticles. This result suggests that the biological molecules (i.e. metabolite) prevent clotting and pairing of the nanoparticles and may perform a function for the formation and stabilization of $\mathrm{Ag} \mathrm{NP}$ in an aqueous medium and seems to have the same functional group as an extract. It is well known that proteins can bind to $\mathrm{Ag} \mathrm{NP}$ through their free amine groups [17, 33] and, it was suggested that if antioxidants \& flavonoid compounds present the in plant extract, are more suitable for the reduction of metal salts like standard antioxidant agents ascorbic acid and gallic acid [36]. Thus by our experimentation, it confirmed that silver nanoparticle of the leaf of Urena lobata was successfully synthesized.

Table-1: Showing phytochemical groups present in Urena lobata

\begin{tabular}{|l|l|l|l|l|l|l|l|l|l|l|}
\hline \multirow{2}{*}{ Test group } & \multicolumn{3}{l|}{ Leaf extract } & \multicolumn{3}{l|}{ Stem extract } & \multicolumn{2}{l|}{ Root extract } \\
\cline { 2 - 12 } & D.W. & MeOH & CHCl3 & D.W. & MeOH & CHCl3 & D.W. & MeOH & CHCl3 \\
\hline Tennis & + & - & - & + & - & - & - & - & - \\
\hline Flavonoid & + & + & + & - & + & - & + & - & - \\
\hline Steroid & + & + & - & + & + & + & + & + & - \\
\hline Alkaloid & + & - & - & - & - & - & + & - & - \\
\hline Saponin & + & - & - & - & - & - & + & + & - \\
\hline Cardiac Glycoside & + & + & - & + & + & - & + & + & - \\
\hline Terpenoid & + & + & & + & + & + & + & + & - \\
\hline Sugar & + & - & - & + & + & - & + & + & - \\
\hline Phenol & + & - & & + & - & - & - & - & - \\
\hline
\end{tabular}

D.W. = distill water, $\mathrm{MeOH}=$ methanol, $\mathrm{CHCl} 3=$ chloroform
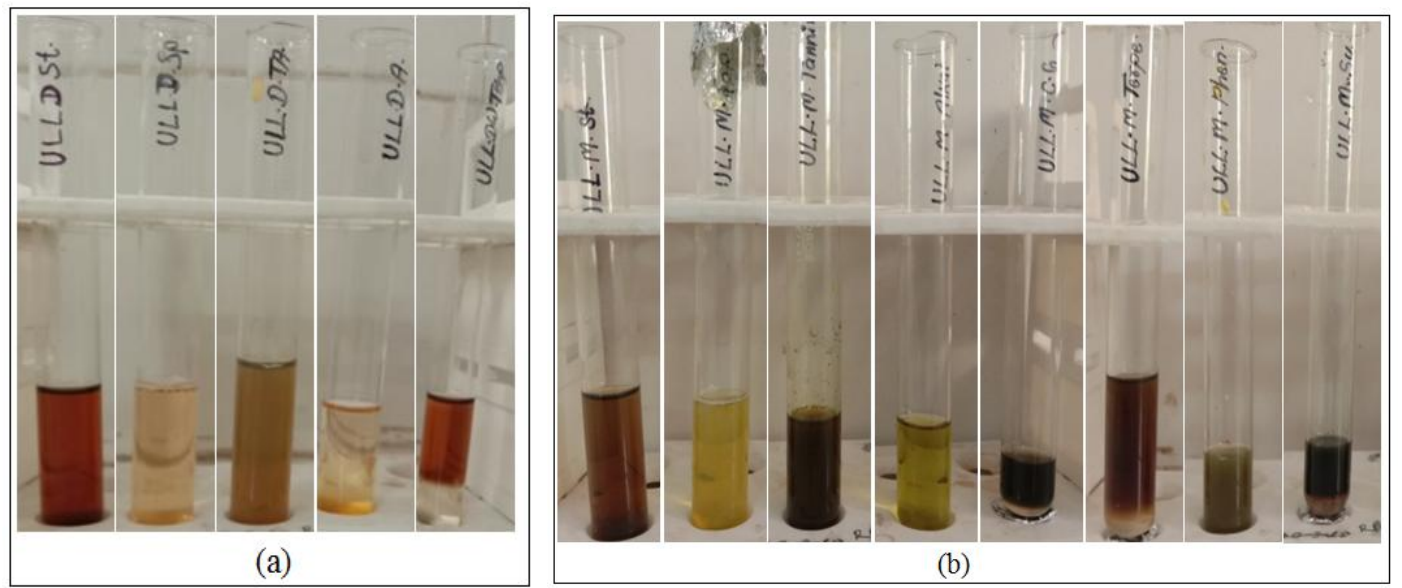


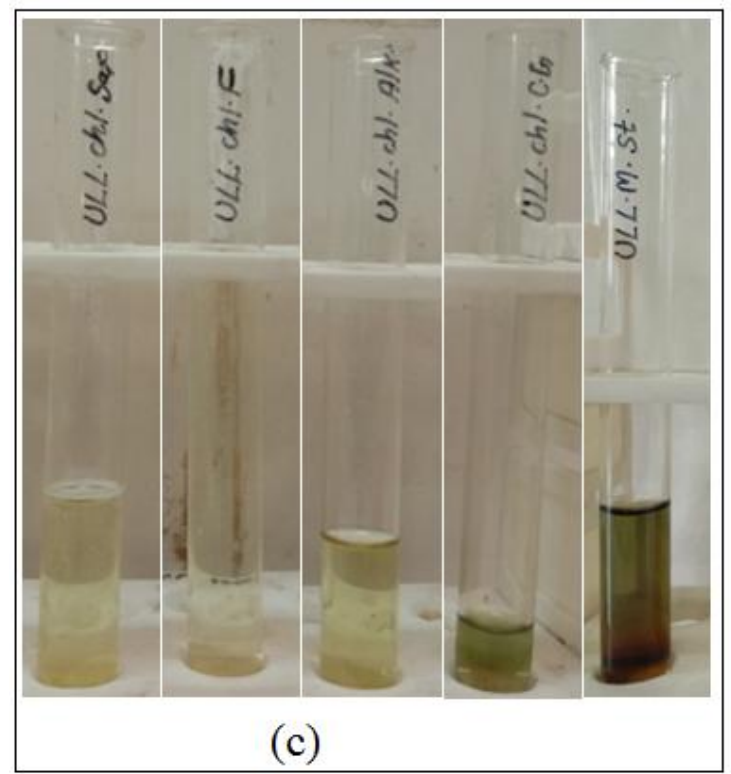

Fig-4: Pictorial representation of phytochemical evaluation of Urena lobata leaf extract -(a) in distilled water, (b) in methanol, and (c) in chloroform

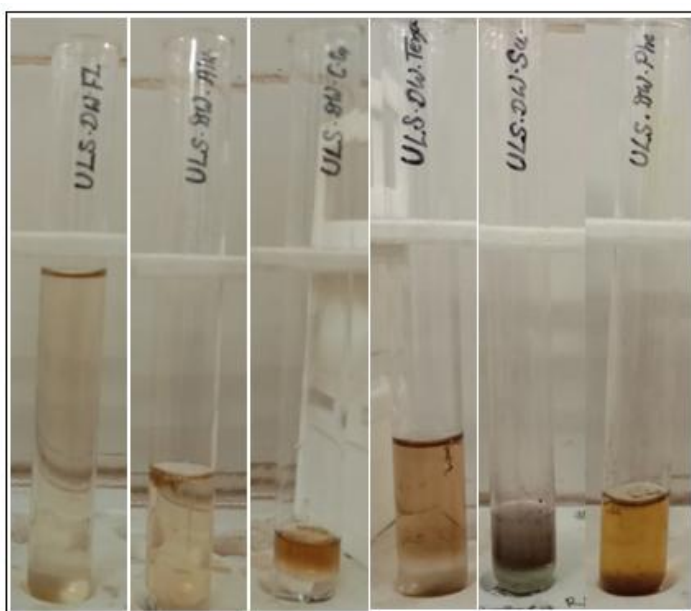

(a)

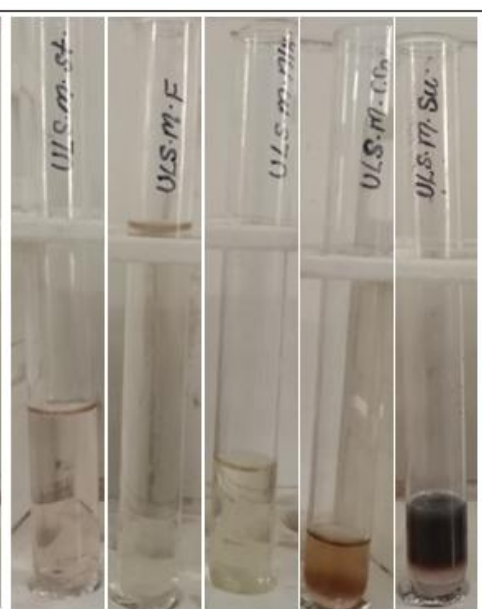

(b)

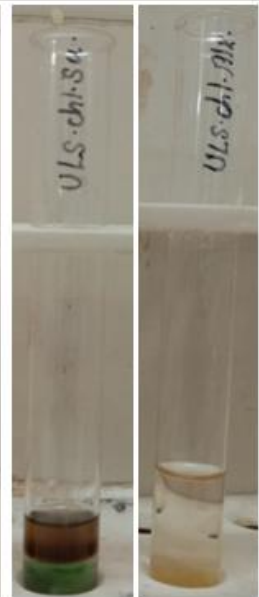

(c)

Fig-5: Pictorial representation of phytochemical evaluation of Urena lobata stem extract -(a) in distilled water, (b) in methanol, and (c) in chloroform

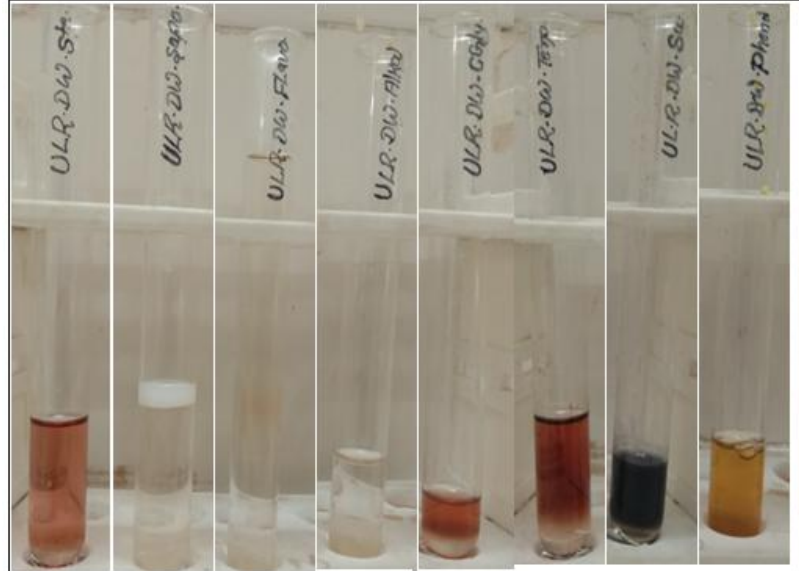

(a)
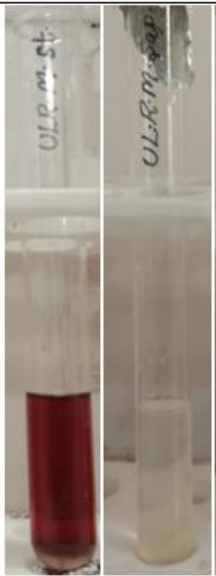

(b)

Fig-6: Pictorial representation of phytochemical evaluation of Urena lobata root extract - (a) in distilled water extract, (b) in methanol extract and 
Table-2: Showing percentage DPPH antioxidant activity

\begin{tabular}{|l|l|l|l|l|}
\hline Sr. No & Test Sample & Concentration & Absorbance (at 517 nm) & Percentage activity \\
\hline 1 & Control & - & 0.160 & 0.000 \\
\hline 2 & Ascarbic acid & $10.0 \mathrm{mg} / \mathrm{ml}$ & 0.010 & 94.44 \\
\hline 3 & Ascarbic acid & $5.0 \mathrm{mg} / \mathrm{ml}$ & 0.010 & 94.44 \\
\hline 4 & Ascarbic acid & $2.5 \mathrm{mg} / \mathrm{ml}$ & 0.020 & 88.88 \\
\hline 5 & Ascarbic acid & $1.2 \mathrm{mg} / \mathrm{ml}$ & 0.050 & 72.22 \\
\hline 6 & Urena lobata & $10.0 \mathrm{mg} / \mathrm{ml}$ & 0.037 & 79.63 \\
\hline 7 & Urena lobata & $5.0 \mathrm{mg} / \mathrm{ml}$ & 0.043 & 75.92 \\
\hline 8 & Urena lobata & $2.5 \mathrm{mg} / \mathrm{ml}$ & 0.047 & 74.07 \\
\hline 9 & Urena lobata & $1.2 \mathrm{mg} / \mathrm{ml}$ & 0.100 & 44.44 \\
\hline
\end{tabular}

\section{DPPH activity}

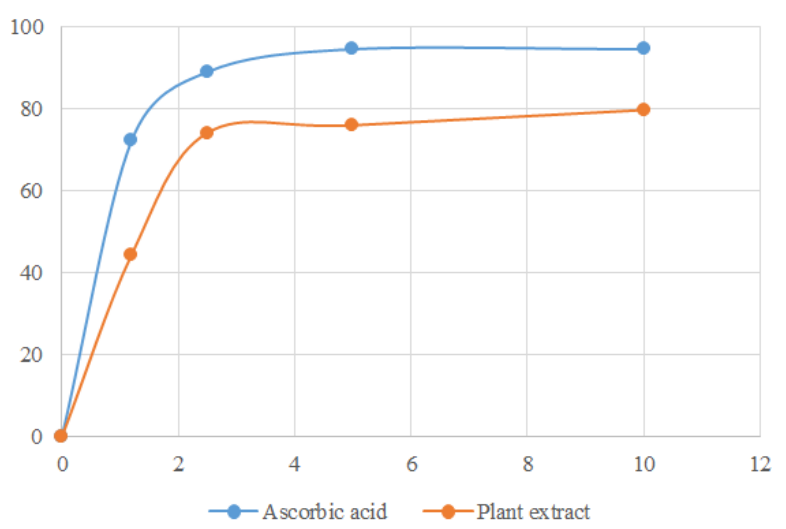

Fig-7: Graphical representation of Antioxidant activity of Urena lobata

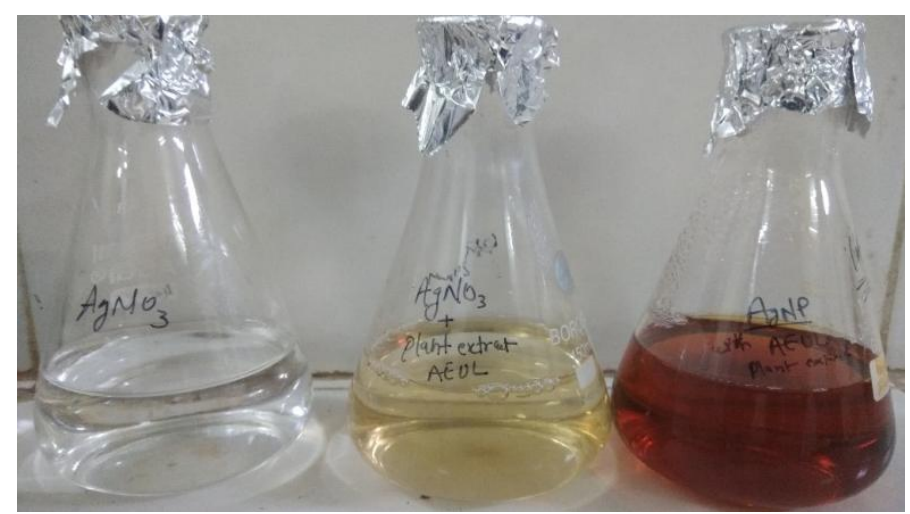

Fig-8: Showing visible indication of nanoparticle synthesis

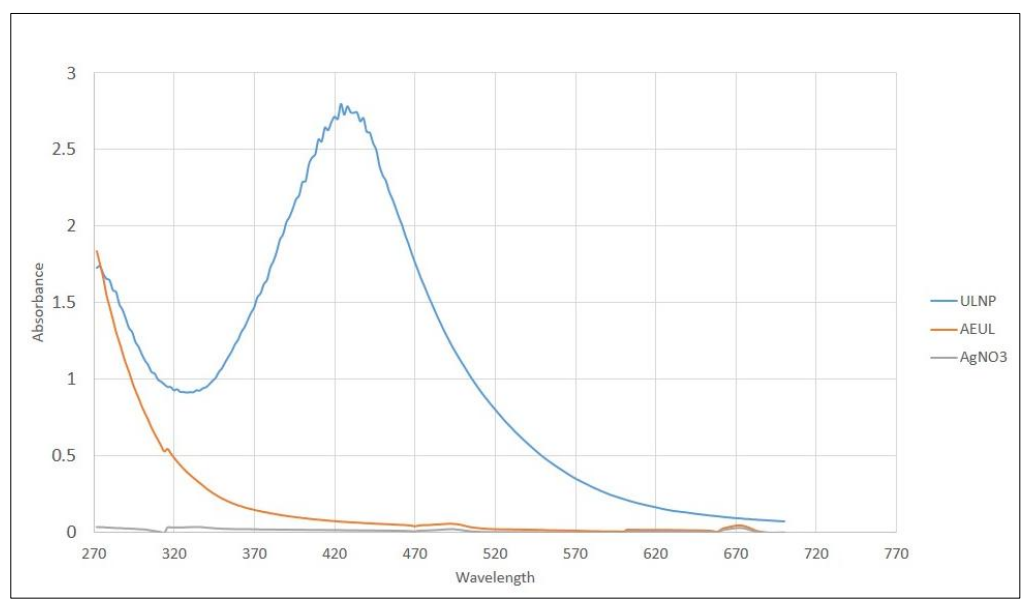

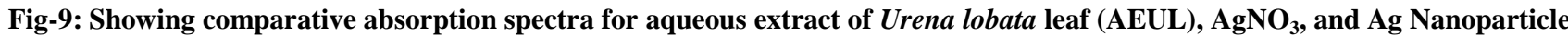
(ULNP) in the UV-VIS range 


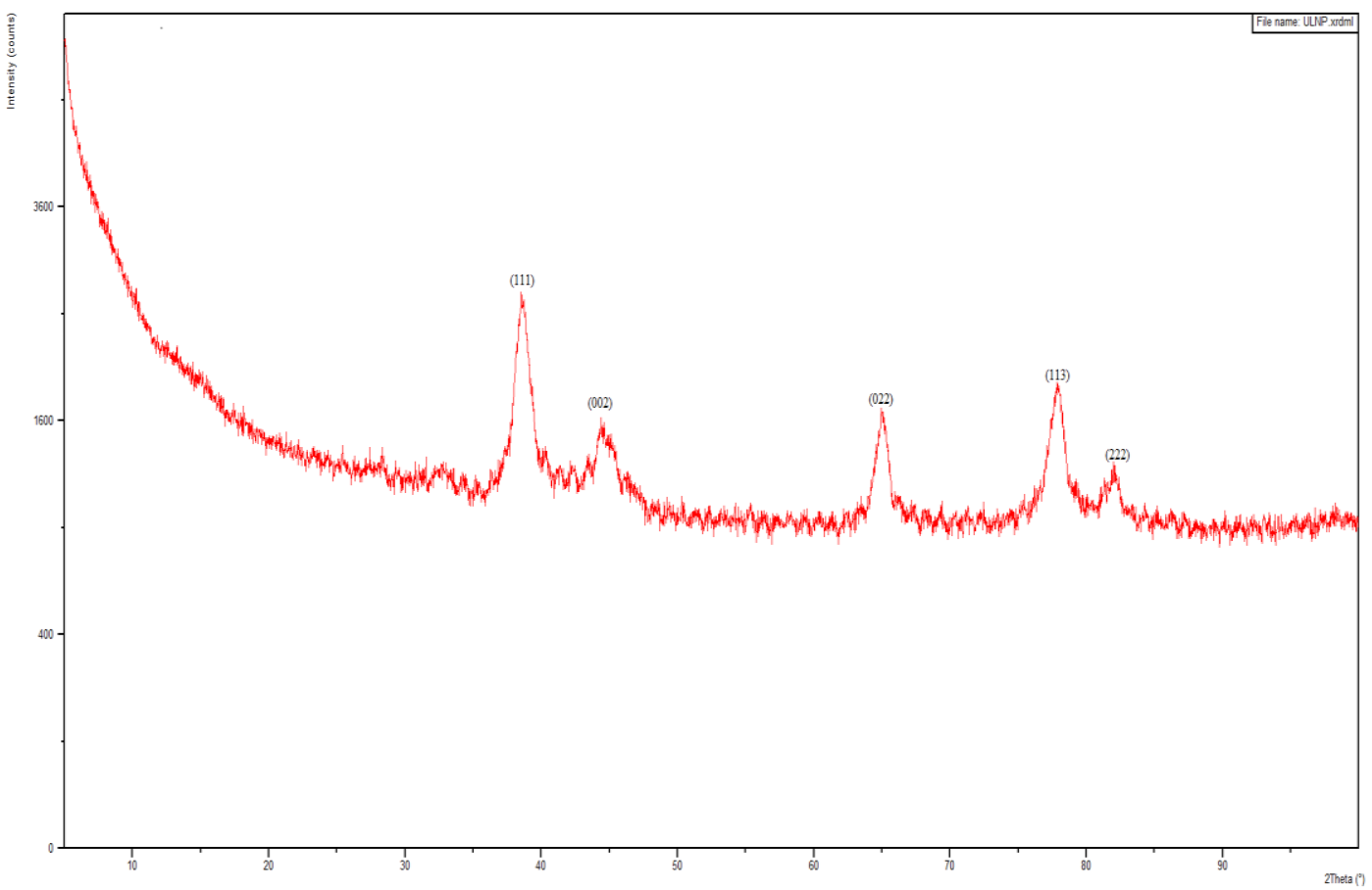

Fig-10: Showing XRD graph of nanoparticle synthesized by Urenal lobat extract with five different peaks between $35^{\circ}-85^{\circ} \theta$ angle; the number above the peaks are hkl number for that respective peak

Table-3: Showing peak list, hkl, $\theta$ angle and their peak intensity for respective peak

\begin{tabular}{|l|c|c|l|l|l|l|}
\hline Peak No. & $\mathrm{h}$ & $\mathrm{k}$ & $\mathrm{l}$ & $\mathrm{d}[\mathrm{A}]$ & 2 Theta[deg] & $\mathrm{I}[\%]$ \\
\hline 1 & 1 & 1 & 1 & 2.34404 & 38.370 & 100.0 \\
\hline 2 & 0 & 0 & 2 & 2.03000 & 44.600 & 47.5 \\
\hline 3 & 0 & 2 & 2 & 1.43543 & 64.910 & 27.7 \\
\hline 4 & 1 & 1 & 3 & 1.22414 & 77.991 & 30.9 \\
\hline 5 & 2 & 2 & 2 & 1.17202 & 82.180 & 8.9 \\
\hline
\end{tabular}

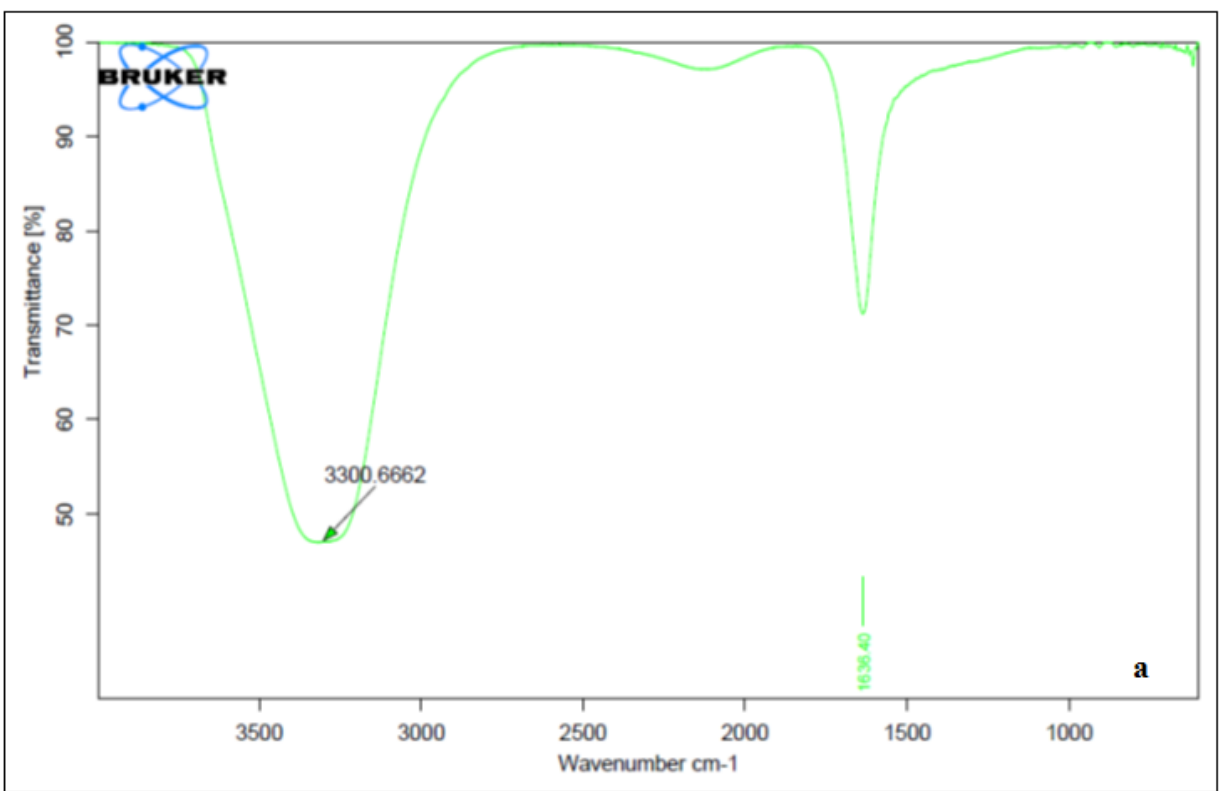




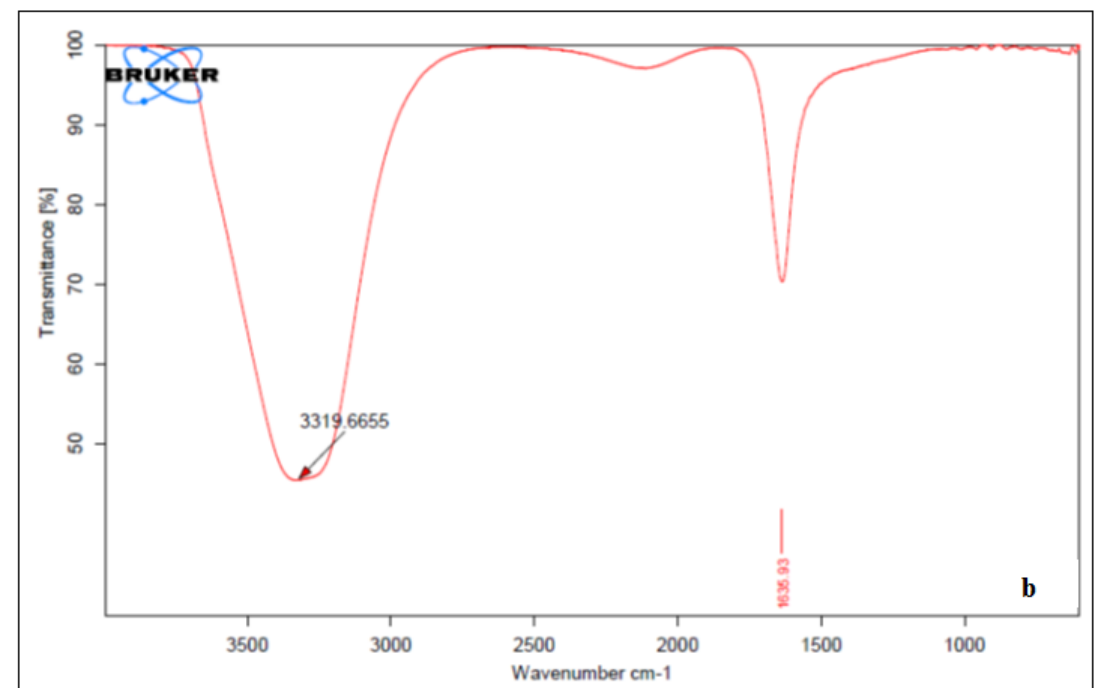

Fig-11: Represent the FTIR spectrum of (a) aqueous extract, and (b) Synthesized silver nanoparticle

\section{CONCLUSION}

Based on the above findings we can conclude that various significant phytoconstituents in Urena lobata have been reported viz. - Tenin, Flavonoids, Steroid, Alkaloid, Saponin, Cardiac glycoside, Terpenoid, Sugar and Phenol. The leaf part having more secondary metabolite than stem and root respectively and better extraction can be done in the aqueous extract in comparison to methanol and chloroform respectively.

The plants having a good antioxidant ability as we confirmed DPPH induced free radical neutralization ability up to $79.62 \%$ and thus suitable for pharmaceutical application.

We have successfully synthesized silver nanoparticle with the leaf of Urena lobata and confirmed by UV-VIS spectrophotometry, FTIR and XRD characterization.

\section{ACKNOWLEDGEMENT}

We acknowledge University Grants Commission, New Delhi for providing grants for the study, NIT Raipur for providing XRD facility, and Department of Chemistry, Govt. V.Y.T.PG. Autonomous college, for providing FTIR facility.

\section{REFERENCES}

1. Ghosh, K. (2004). A furocoumarin, Imperatorin isolated from Urena lobata L. (Malvaceae). Molbank, (1), M382.

2. Islam, M., \& Uddin, M. (2017). A revision on Urena lobata L. Int J Med. 5(1):126.

3. Su, C., Qi, B., Wang, J., Ding, N., Wu, Y., Shi, X. P. (2018). Megastigmane glycosides from Urena lobata. Fitoterapia, 127, 123-128.

4. Purnomo, Y., Soeatmadji, D. W., Sumitro, S. B., \& Widodo, M. A. (2015). Anti-diabetic potential of Urena lobata leaf extract through inhibition of dipeptidyl peptidase IV activity. Asian Pac J Trop Biomed, 5(8), 645-659.

5. Yang, Y., Huang, Z., Zou, X., Zhong, X., Liang, X., \& Zhou, J. (2017). The antibacterial effect of Urena lobata L. Fromv guangxi on mice with Staphylococcus aureus pneumonia. African $J$ Tradit Complement Altern Med. 14(1):73-88.

6. Klaus, T., Olsson, E., \& Granqvist, C. G. (1999). Silver-based crystalline nanoparticles, microbially fabricated.. Proc Natl Acad Sci USA, 96, 13611-13614.

7. Singhal, G., Kasariya, K., Sharma, A. R., \& Singh, R. P. (2011). Biosynthesis of silver nanoparticles using Ocimum sanctum (Tulsi) leaf extract and screening its antimicrobial activity. $J$ Nanopart Res, 13, 2981-2988.

8. Dobruckam, R. (2019). Biofabrication of platinum nanoparticles using Fumariae herbal extract and their catalytic properties. Saudi Journal of Biological Sciences, 26, 31-37.

9. Huang, Y., Li, X., Liao, Z., Zhang, G., Liu, Q., Tang, J., Peng, Y., Liu, X., \& Luo, Q. (2007). A randomized comparative trial between Acticoat and SD-Ag in the treatment of residual burn wounds including safety analysis. Burns, 33, 161-166.

10. Li, W. R., Xie, X. B., Shi, Q. S., Duan, S. S., Ouyang, Y. S., \& Chen Y. B. (2011). Antibacterial effect of silver nanoparticles on Staphylococcus aureus. Biometals, 24, 135-141.

11. Cox. S. G., Cullingworth, L., \& Rode, H. (2011). Treatment of pediatric burns with a nanocrystalline silver dressing compared with standard wound care in a burns unit: A cost analysis. S Afr Med J. 101, 728-731.

12. Pollini, M., Paladini, F., Catalno, M., Taurino, A., Licciulli, A., Maffezzoli, A., \& Sannio, A. (2011). Antibacterial coatings on haemodialysis catheters by photochemical deposition of silver nanoparticles. J Mater Sci Mater Med. 22, 20052012. 
13. Nelson, D. P. D., Oswaldo, L. A., Gabriel, I. H. D. S, Elisa, E. (2005). Mechanical aspects of biosynthesis of silver nanoparticles by several Fusarium oxysporum strains. Journal of Nanobiotechnology, 3, 8 .

14. Hemanth, N. K. S., Karthik, L., \& Bhaskara, R. K. V. (2010). Extracellular biosynthesis of silver nanoparticles using the filamentous fungus Penicillium sp. Arch Appl Sci Res, 2(6), 161167.

15. Natarajan, K., \& Ramchandra, M. (2010). Microbial production of silver nanoparticles. Dig J Nanomat Bios, 5(1), 135-140.

16. Ankamwar, B. D. C., Ahmad, A., \& Sastry, M. (2005). Biosynthesis of gold and silver nanoparticles using Emblics Officinalis Fruit extract and their Phase Transfer and Transmetallation in an Organic Solution.. $J$ nanosci nanotechnology, 5(10), 1665-1671.

17. Ahmed. S., Saifullah., Ahmad, M., Swami, B. L., Ikram. S. (2016). Green synthesis of silver nanoparticles using Azadirachta indica aqueous leaf extract. Journal of Radiation Research and Applied Science, 9, 1-7.

18. Harbone, J. B. (1998). Phytochemical MethodsA Guide to Modern Techniques of Plant Analysis. Chapman and Hall, London. 182-190.

19. Trease, G., \& Evans, S. M. (2002). Pharmacognosy. 15th Edi. London: Bailer Tindal. 23-67.

20. Elgorashi, E. E., \& Staden, V. J. (2004). Pharmacological screening of six Amaryllidaceae species. J Ethnopharmacol. 90, 27-32.

21. Khalil, M. M. H. (2014). Green synthesis of silver nanoparticles using olive leaf extract and its antibacterial activity. Arab J Chem. 7(6):1-9.

22. Islam, T., Ibrahim, M., Ahsan, M. Q., Mohi, Uddin, Chowdhury M., Hossain, M. A., \& Rashid, M. A. (2012). Phytochemical and pharmacological investigations of Uraria lagopodies DC. and Urena lobata L. Dhaka Univ J Pharm Sci. 11(1):65-69.

23. Fagbohun, E. D., Asareand, R. R., \& Egbebi, A. O. (2012). Chemical composition and antimicrobial activities of Urena lobata L. (Malvaceae). Journal of Medicinal Plants Research, 6(12), 2256-2260.

24. Aiyegoro, O. A., \& Okoh A, I. (2010). Preliminary phytochemical screening and In vitro antioxidant activities of the aqueous extract of Helichrysum longifolium DC. BMC Complementary and Alternative Medicine, 10, 1-8.

25. Sankhalkar, S., \& Vernekar, V. (2016). Quantitative and Qualitative Analysis of Phenolic and Flavonoid Content in Moringa oleifera Lam and Ocimum tenuiflorum L., Pharmacognosy Res. 8(1):16-21.

26. Gao, X. L., Liao, Y., Wang, J., Liu, X.Y., Zhong, K., Huang, Y. N. (2015). Discovery of a potent anti-yeast triterpenoid saponin, clematoside-S from Urena lobata L. Int $\mathrm{J} \mathrm{Mol}$ Sci. 16(3), 4731-43.

27. Gowri, S. S., \& Vasantha, K. (2010), Phytochemical Screening and Antibacterial Activity of Syzygium cumini (L.) (Myrtaceae) Leaves Extracts. International Journal of PharmTech Research, 2(2), 1569-1573.

28. Matlawska, I., \& Sikorska, M. (1999). Flavonoid Compounds From U. Lobata. Acta Pol. Pharm. 56(1), 69-71.

29. Singh, D., Singh, V. (2015). Isolation and Characterization of Flavonoids in Urena lobata Leaves. European J Med Plants, 2015;11(1):16.

30. Lissy, K. P., Simon, T. K., \& Latha, M. S. (2006) Antioxidant potential of Sida retusa, Urena lobata and Triumfetta rhomboidea. Anc Sci Life, XXV, 10-5.

31. Ali, M. S., Omar, Rahman, F., K., Aslam, M., \& Hossain, M. A. (2013). Antioxidant and Cytotoxic Activities of Methanol Extract of Urena lobata (L) Leaves. Pharma Innov. 2(2), 9-14.

32. Ahmad, A., Mukherjee, P., Senapati, S., Mandal, D., Khan, M. I., \& Kumar, R. (2003). Extracellular biosynthesis of silver nanoparticles using the fungus Fusarium oxysporum colloids and surfaces B. Biointerfaces, 28, 313-318.

33. Raja, S., Ramesh, V., \& Thivaharan, V. (2017). Green biosynthesis of silver nanoparticles using Calliandra haematocephala leaf extract, their antibacterial activity and hydrogen peroxide sensing capability. Arab J Chem, 10(2), 253261.

34. Logeswari, P., Silambarasan, S., \& Abraham, J. (2013). Eco-friendly synthesis of silver nanoparticles from commercially available plant powders and their antibacterial properties. Scientia Iranica F, 20(3), 1049-1054.

35. Moosa, A. A., Ridha, A. M., Al-Kaser, M. (2015). Process Parameters for Green Synthesis of Silver Nanoparticles using Leaves Extract of Aloe Vera Plant. International Journal of Multidisciplinary and Current Research, 3, 966975.

36. Bagherzade, G., Tavakoli, M. M., \& Namaei, M. H., (2017). Green synthesis of silver nanoparticles using aqueous extract of saffron (Crocus sativus L.) wastages and its antibacterial activity against six bacteria. Asian Pac J Trop Biomed, 7(3), 227-33. 